\title{
L'HABITAT À UNE ÉCHELLE GLOBALE : IMPORTANCE RESPECTIVE DE L'IMMIGRATION ET DE L'EXTINCTION POUR LES PEUPLEMENTS DE POISSONS DES PETITS LACS.
}

\author{
W.M. TONN, R.E. VANDENBOS et C.A. PASZKOWSKI \\ Department of Biological Sciences, University of Alberta, \\ Edmonton, Alberta T6G 2E9, Canada.
}

\begin{abstract}
RÉSUMÉ (traduit par les éditeurs)
\end{abstract}
Les deux processus qui déterminent la structure des communautés dans les habitats insulaires sont l'immigration d'espèces vers une communauté et l'extinction de celles qui étaient présentes auparavant. Bien que l'immigration et l'extinction se produisent généralement à des échelles supérieures à celles qu'il est possible d'étudier avec des expériences plannifiées, les écologistes peuvent améliorer leur compréhension de ces processus par l'analyse des distributions observées ; l'isolation, le caractère discret et la réplication des systèmes insulaires présentent des avantages pour réaliser de telles analyses. Comme pour les communautés observées sur de vraies îles, la structure des peuplements de poissons dans les petits lacs forestiers est le résultat de l'immigration et de l'extinction. L'importance relative de ces processus peut dépendre des caractéristiques d'habitat des lacs et des espèces présentes, ainsi que du cadre régional et historique des lacs étudiés. Dans une région donnée, la composition des peuplements locaux de poissons peut être reliée à un ensemble particulier de conditions d'habitat et, dans la mesure où ces facteurs peuvent être liés à l'immigration et à l'extinction, il devrait être possible d'analyser les relations peuplement-environnement pour en déduire l'importance relative de ces processus dans la formation de peuplements locaux dans et entre les régions et les continents. Nous avons réalisé des analyses à large échelle des relations peuplementenvironnement des petits lacs forestiers de quatre régions tempérées d'Europe et d'Amérique du Nord ; I'utilisation d'une série d'analyses canonique partielle des correspondances nous a permis de distinguer la variation due aux relations peuplementsenvironnement d'un ensemble de facteurs associés à l'immigration contre l'extinction. Les isolations passées et présentes varient selon les lacs et les régions, comme la composition et la richesse des groupes régionaux d'espèces. Néanmoins, pour les peuplements de poissons des petits lacs forestiers de Suède, de Finlande, du Wisconsin (USA) et d'Alberta (Canada), 60 à $78 \%$ de la variation est expliquée par les variables liées à l'extinction, indépendemment des facteurs liés à l'immigration; 9 à $27 \%$ de la variation restante sont expliqués par les deux composants. Dans les petits lacs forestiers, la sévérité des conditions abiotiques peut limiter les espèces les moins tolérantes s'il n'existe pas de refuge à ces conditions. Les interactions entre espèces, qui sont souvent intenses et peuvent augmenter la probabilité d'extinction locale (ou s'opposer à la réussite de la colonisation), peuvent ne pas avoir d'action si les espèces devant potentiellement interagir présentent une sensibilité différentielle aux rigueurs de l'environnement ou à d'autres facteurs liés à l'extinction. Nos résultats suggèrent que, peut-être parce que les taux d'immigration des petits lacs forestiers ne sont pas importants, les variables d'habitat liées à l'extinction sont les plus fortement associées aux distributions de peuplements piscicoles observés.

\section{HABITAT ON A BROAD SCALE : RELATIVE IMPORTANCE OF IMMIGRATION AND EXTINCTION FOR SMALL LAKE FISH ASSEMBLAGES.}

\section{SUMMARY}

Two processes that determine community structure in insular habitats are the immigration of species into a community and the extinction of species that were previously present. Although immigration and extinction usually occur at scales beyond what is possible to study with planned experiments, ecologists can gain understanding of these 
processes from inferences based on present-day distributions; the isolation, discreteness and replication of insular systems offer advantages for making such inferences. As with communities on true islands, the structure of fish assemblages in small forest lakes are the products of immigration and extinction. The relative importance of these processes can depend upon the habitat characteristics of the lakes, characteristics of the available species, and on the regional and historic setting of the lakes being studied. Within a given region, the composition of local fish assemblages can be related to specific sets of habitat factors, and because these factors can be linked to immigration and extinction, it should be possible to analyze assemblage-environment relations to infer the relative importance of these processes in shaping local assemblages within and between regions and continents. We have conducted broad-scale analyses of assemblage-environment relations in small forest lakes of four north-temperate regions of Europe and North America ; using a series of partial canonical correspondence analyses, we can apportion the variation in assemblageenvironment relations between sets of factors associated with immigration versus extinction. Past and present isolation varies among lakes and regions, as does the composition and richness of regional species pools. Nevertheless, for fish assemblages in small forest lakes of Sweden, Finland, Wisconsin (USA) and Alberta (Canada), extinctionrelated variables accounted for $60-78 \%$ of the explained variation, independent of immigration factors; another 9-27\% was shared by the two components. In small forest lakes, severity of the abiotic environment can filter out intolerant species unless a refuge from such conditions is available. Species interactions, which are often intense and can increase the probability of local extinction (or prevent successful colonization), can be circumvented if potentially interacting species are differentially sensitive to environmental severity or other extinction-related factors. Our results suggest that, perhaps because immigration rates into small forest lakes are not high, extinction-related habitat variables are most strongly associated with the observed patterns of fish assemblages.

\section{INTRODUCTION}

Ecologists have long recognized and appreciated that community-level patterns are not static but develop continuously as a result of past and present dynamic processes (GLEASON, 1926). Two processes that result in community change through time and community patterns in space are immigration of species into a community and extinction of species previously present. For species to become and remain part of a community, (i) the community must be located where dispersing individuals are able to reach it, and (ii) suitable habitat(s) must be present to allow immigrants to withstand the biotic and abiotic conditions present so that viable populations can be established and maintained. However, the species available to colonize a local site are the product of a series of filters acting at many different spatial and temporal scales, which allow only a portion of the species that might be available to pass through (SIMPSON, 1953 ; HOLMES, 1986 ; LOMOLINO, 1986).

Understanding why a given habitat or community is prone to or immune from immigration or contains populations subject to local extinctions are important goals of community and landscape ecology (ROBINSON and DICKERSON, 1984 ; MOULTON and PIMM, 1986 ; WIENS et al., 1993) ; understanding the processes of immigration and extinction is also important in the study of metapopulations and conservation biology (MOONEY and DRAKE, 1986 ; HOLT, 1992 ; THOMAS, 1994). Studying the fate of invasions into natural communities - why particular ones occurred, why they succeeded or failed - may sometimes suffer from imperfections of experimental design because such invasions usually occur at scales far beyond what is possible with planned experiments. Nevertheless, because of the importance of these processes, studies focusing on immigration and local extinction can provide important clues into community organization and tests of theoretical models of communities (DIAMOND and CASE, 1986).

Despite the fact that relatively few invasions, both successful and failed, have been documented during historic times, ecologists have been able to gain understanding from studying invasions that have not been witnessed but are inferred from present-day distributions of species at a number of sites within an archipelago (WILLIAMS, 1983 ; DIAMOND and CASE, 1986 ; ROUGHGARDEN, 1986). Immigration and extinction can be especially important for determining richness and composition of insular communities 
(MACARTHUR and WILSON, 1967 ; MAGNUSON, 1976). The isolation, discreteness, and replication of these island systems offer well-known advantages for making inferences (DIAMOND, 1986).

Because insular communities are shaped by the processes of immigration and extinction, it is not surprising that interpretations of one general pattern of insular communities, the species-area relation, frequently rely on immigration and/or extinction in one way or another (but see CONNOR and MCCOY, 1979 ; RAHEL, 1986). However, although area may directly affect the rates of immigration and extinction, it may also simply represent an index for other characteristics that affect these processes (MCGUINESS, 1984).

Because of this, it can be difficult to identify and understand the relative importance of immigration, successful colonization and extinction in determining the richness and composition of an island community simply from a species-area relation. However, a number of other habitat characteristics affect island richness and composition through their influence on immigration and extinction. Isolation from a source of immigrants may lower the probability of invasion (MACARTHUR and WILSON, 1967 ; DIAMOND 1972 ; ROBINSON and DICKERSON, 1987) ; the richness and composition of the regional pool of potential immigrants may similarly affect invasion probabilities (CORNELL, 1986). A system's age and position in the landscape may alter the relative importance of immigration and extinction, and thus affect the present-day community structure (OSBORNE and WILEY, 1992 ; MCCORMICK and CAIRNS, 1992 ; SALE et al., 1994). Habitat diversity can affect the success of immigrants (BRORING, 1991) and habitat severity and the absence of refuges from stress may increase extinction rates for intolerant species (LEVINS and HEATWOLE, 1973 ; BUHL-MORTENSON and HØISAETER, 1993). Finally, biotic interactions with the island's residents can also influence the chance that an arriving immigrant will successfully colonize or go extinct (LEVINS and HEATWOLE, 1973 ; MOULTON and PIMM, 1983 ; SILVERTOWN and WILSON, 1994).

The complexity created by a multiplicity of potential factors, the absence of experimental control, and problems in formulating appropriate null hypotheses and statistical tests can create difficulties for geographical community ecologists. However, comparative approaches combined with multivariate statistical applications (ter BRAAK, 1991 ; BORCARD et al., 1992 ; MAGNAN et al., 1995) can help identify the relative importance of different environmental components to community-level patterns in insular habitats.

Lakes are insular habitats with many of the characteristics of oceanic islands (MAGNUSON, 1976 ; BROWNE, 1981 ; EADIE et al., 1986). Both lakes and islands are small, isolated habitats imbedded within an inhospitable matrix. Both lakes and islands are young habitats when compared with continents and oceans, e.g., small forest lakes in glaciated regions of the Holarctic are $<12,000$ yrs old. As with island communities, the composition of fish assemblages of small forest lakes can be understood in terms of a series of filters, operating at a number of spatial and temporal scales, that determine the composition of the available species pool and affect rates of immigration and extinction (TONN, 1990). Some small lakes are isolated remnants of large glacial lakes and thus are analogous to land-bridge islands (NORDQUIST, 1903) ; for other lakes, colonized postglacially via watemways, their degree of isolation or geographic position may affect rates of invasion of fishes from the regional or drainage-system species pools (TONN and MAGNUSON, 1982 ; HINCH et al., 1991 ; MAGNAN et al., 1995). Species-area relations have been documented for a number of lake sets (e.g., BROWNE,1981; EADIE and KEAST, 1984), as have relations between species richness, habitat complexity, and productivity (e.g., TONN and MAGNUSON, 1982 ; BENSON and MAGNUSON, 1992). Environmental severity can be continuous (e.g., low pH) or episodic (low winter oxygen) and unless refuges are available, such conditions can increase extinction rates by filtering out intolerant species (TONN and MAGNUSON, 1982 ; RAHEL and MAGNUSON, 1983 ; RASK, 1987). Because of small population sizes and reduced habitat heterogeneity, species interactions may be intense and also lead to extinction or prevent successful colonization (SVÄRDSON, 1976). Alternatively, the intensity of biotic interactions may be reduced if, for example, predators are filtered out of a system, permitting successful colonization by prey (ROBINSON and TONN, 1989). 
Because we can relate the composition of fish assemblages in small forest lakes to specific sets of environmental factors, and because these factors can be linked to immigration and extinction of species, it should be possible to analyze assemblageenvironment relations to assess the potential importance of these processes for fish assemblages in the lakes of a region. In this study, we apply the approach of partialling out components of ecological variation in multivariate community-environment data (BORCARD et al., 1992) to data sets compiled from North America and northern Europe. The use of these data sets, involving faunistically-distinct regions, each with a number of identifiable assemblage types, should also allow us to assess the robustness and generality of our conclusions. Specifically, we addressed the following questions. (1) Using fish assemblage - lake environment relations derived from multi-lake surveys, can we infer the relative importance of immigration and extinction in determining community structure ? (2) How do these patterns vary between regions and continents ? (3) Among the characteristics of a lake, what is the relative importance of its geographic setting, morphometry and water chemistry?

\section{METHODS}

\section{Data Sets}

We compiled data sets of fish assemblages and environmental characteristics from lakes in four glaciated north-temperate or boreal regions: Sweden, Finland, Wisconsin (USA) and Alberta (Canada) (Table 1).

Sweden.- Swedish lakes were taken from a large data set (1300 lakes) compiled from different monitoring programs conducted over the last 20 y (W. TONN, L., GREENBERG and C. PASZKOWSKI, unpublished data). Sampling was primarily conducted by the Swedish National Board of Fisheries or by county governments. A standardized gillnetting technique, involving multi-mesh benthic gillnets (NYBERG and DEGERMAN, 1988), provided data on the relative abundances (by biomass) of each species in each lake. The number of nets used was related to lake size (area and depth), and ranged between 4 and 90 nets. Limnological data were obtained from the Swedish Environmental Protection Agency and from county governments. Other environmental data were obtained from SMHI (1983) and from topographic maps.

In constructing the data set for this study we considered only those lakes for which we had data on watershed area $(\mathrm{N}=418)$, as this is an important variable related to immigration at the local scale (TONN and MAGNUSON, 1982). From these 418 lakes, a data set of 100 lakes was constructed (Table 1) by first examining the north-south distribution of lakes, in 100-km units (as determined from the X-coordinate of the lakes on the "grid of Sweden" ; SMHI, 1983). A stratified-random selection procedure was then used to maximally spread the distribution of 100 lakes among these $100-\mathrm{km}$ latitudinal units (within the constraints imposed by the distribution of the original 418 lakes). The resulting 100 lakes contained a total of 23 fish species ; following standard community analysis procedures (GAUCH, 1982), six rare species were omitted from analyses.

Finland. - Fish assemblage data for 113 lakes in southern and central Finland $\left(60-67^{\circ} \mathrm{N}\right)$, consisting of the relative abundances of 20 species, were obtained from TONN et al. (1990). Eleven rare species, occurring in five or fewer lakes, were omitted from analyses. Environmental data for these lakes, which were fairly small but chemically heterogeneous (Table 1), were obtained from the original sources of the fish data or from topographic maps (see TONN et al., 1990).

Wisconsin.- TONN et al. (1990) also provided data on fish assemblage composition (presence-absence) and environmental characteristics for 51 lakes in northern Wisconsin $\left(45-46^{\circ} \mathrm{N}\right.$ ). Eleven rare species (out of 23 ) were omitted prior to analyses. Wisconsin lakes were also small but limnologically varied (Table 1). Additional environmental data were obtained from topographic maps (J. MAGNUSON and W. TONN, unpublished data).

Alberta. - Fish species composition (presence-absence) and environmental characteristics have recently been collected for 33 lakes in north-central Alberta $\left(54-55^{\circ} \mathrm{N}\right.$; C. PASZKOWSKI, W. TONN and R. VANDENBOS, unpublished data). Fish were sampled 
Tableau I : Médianes et domaine de variation des variables environnementales utilisées dans les analyses multivariées et résumé des richesses spécifiques en poissons pour les quatre régions. Les variables environnementales sont regroupées sur la base des processus d'immigration ou d'extinction auxquels elles contribuent.

Table I : Medians and ranges for environmental variables used in multivariate analyses and a summary of fish species richness for the four regions. Environmental variables are grouped based on the process, immigration or extinction, which they contribute towards.

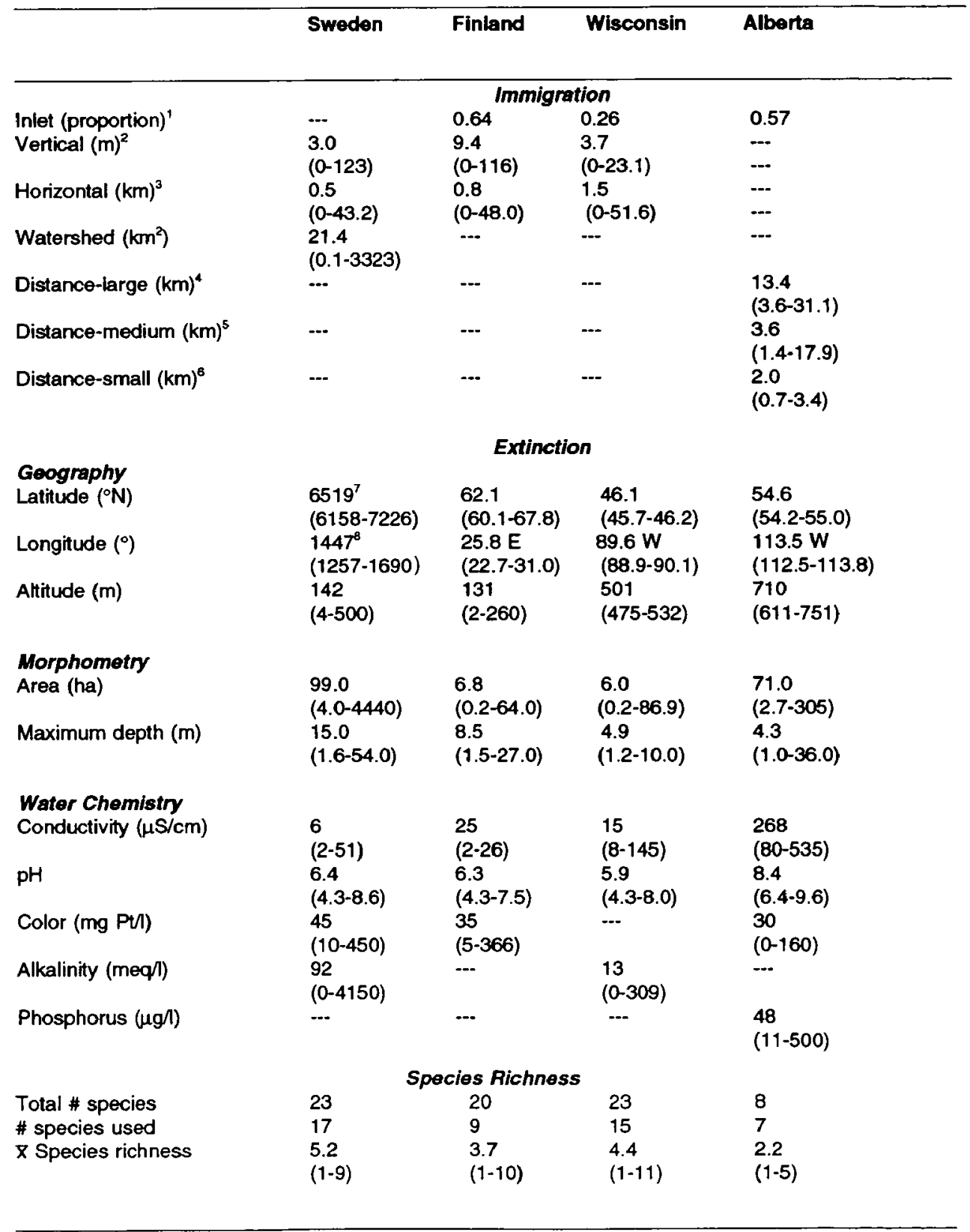

\footnotetext{
'Inlet present $=1$, absent $=0,{ }^{2}$ Vertical distance to next lake downstream, ${ }^{3}$ Horizontal distance to nearest lake, "Horizontal distance to nearest lake $\geq 2.7 \mathrm{ha},{ }^{5}$ Horizontal distance to nearest lake $\geq 71 \mathrm{ha}$, ${ }^{6}$ Horizontal distance to nearest lake $\geq 305 \mathrm{ha},{ }^{7} X$ coordinate in Swedish grid system, $=\mathrm{km}$ to equator,

${ }^{8} Y$ coordinate in Swedish grid system, $=\mathrm{km}$ to Greenwich 0 meridian.
} 
with multi-mesh gill nets, minnow traps and small fyke nets. Environmental characteristics were measured with a Hydrolab Surveyor II multiprobe, determined from water samples collected from just below the surface or obtained from topographic maps. Alberta's regional fish fauna is depauperate (NELSON and PAETZ, 1992); of the eight species encountered, one was considered rare and omitted from analyses. In contrast to the other regions, Alberta lakes are primarily well-buffered, basic and nutrient-rich, but because surface drainage is poorly developed, they are frequently subject to "winterkill" conditions, especially in isolated systems.

\section{Analyses}

Fish data for Finland and Sweden were transformed from relative abundance to the octave scale of GAUCH (1982). Environmental data were $\log _{10}$-transformed, except for $\mathrm{pH}$ and the presence/absence of an inlet or outlet stream. In the few cases where individual lakes lacked a measurement for a particular environmental factor, the mean value for the data set was used.

To identify overall patterns in fish assemblage composition, and the relationships of these patterns to the environmental variables, we applied the constrained ordination technique of canonical correspondence analyses (CCA ; ter BRAAK, 1991) to each data set ; we first used all environmental variables available for a particular data set, and then used forward-selection of environmental variables, to rank variables based on the amount of variation they explained for the fish assemblage data.

To assess the potential importance of immigration and extinction in contributing to these community patterns, we partitioned the variation in the fish data that could be explained by independent environmental components (and their overlap) by applying a series of partial CCAs to each data set (BORCARD et al., 1992). Environmental variables were classified as being related to immigration (factors associated with the isolation or connectedness of individual lakes ; Table 1) or to extinction, i.e., geographical (climatic) and habitat factors (morphometry and water chemistry) associated with the probability of a colonizing species establishing and maintaining a viable population in a lake (Table 1). Because our data sets contained more extinction than immigration variables, we also employed the BORCARD et al. (1992) procedure of using only the first $n$ components (where $n=$ the number of immigration factors) from principal components analyses (PCA) of the lakes-by-extinction-factors data matrices. In addition, we performed a series of analyses that used equal numbers of immigration and extinction variables, with the latter chosen by the forward selection procedure of the CANOCO program (ter BRAAK, 1991).

\section{RESULTS}

\section{General community-level patterns}

Overall patterns, including those associated with the relative importance of immigration and extinction, were similar for all four data sets ; this similarity held regardless of whether we used all extinction-related variables, the first $n$ components of a lakes-byextinction PCA, or the forward selection procedure to choose extinction variables. For simplicity, we report below only results from analyses using all variables.

Sweden. - Canonical correspondence analysis accounted for $34 \%$ of the variation in the Swedish fish assemblages. Within the CCA ordination, most fish assemblages were aligned along a central continuum, with a small set of lakes trailing off to the upper right-hand corner (Fig. 1). Crucian carp (along with rudd and tench; see Appendix for a list of common and scientific names, and abbreviations used) were characteristic of assemblages at one end of the continuum ; crucian lakes were small, shallow and isolated (positively correlated with horizontal and vertical distances to the next downstream lake), and also had high values for alkalinity and conductivity. Zander and bleak characterized lakes at the other end of the continuum ; a core group consisting of perch, pike, roach and ruffe characterized lakes in the continuum's middle. A few deeper lakes at higher altitudes and latitudes (Swedish $\mathrm{X}$-coordinate) were characterized by brown trout and Arctic charr. 

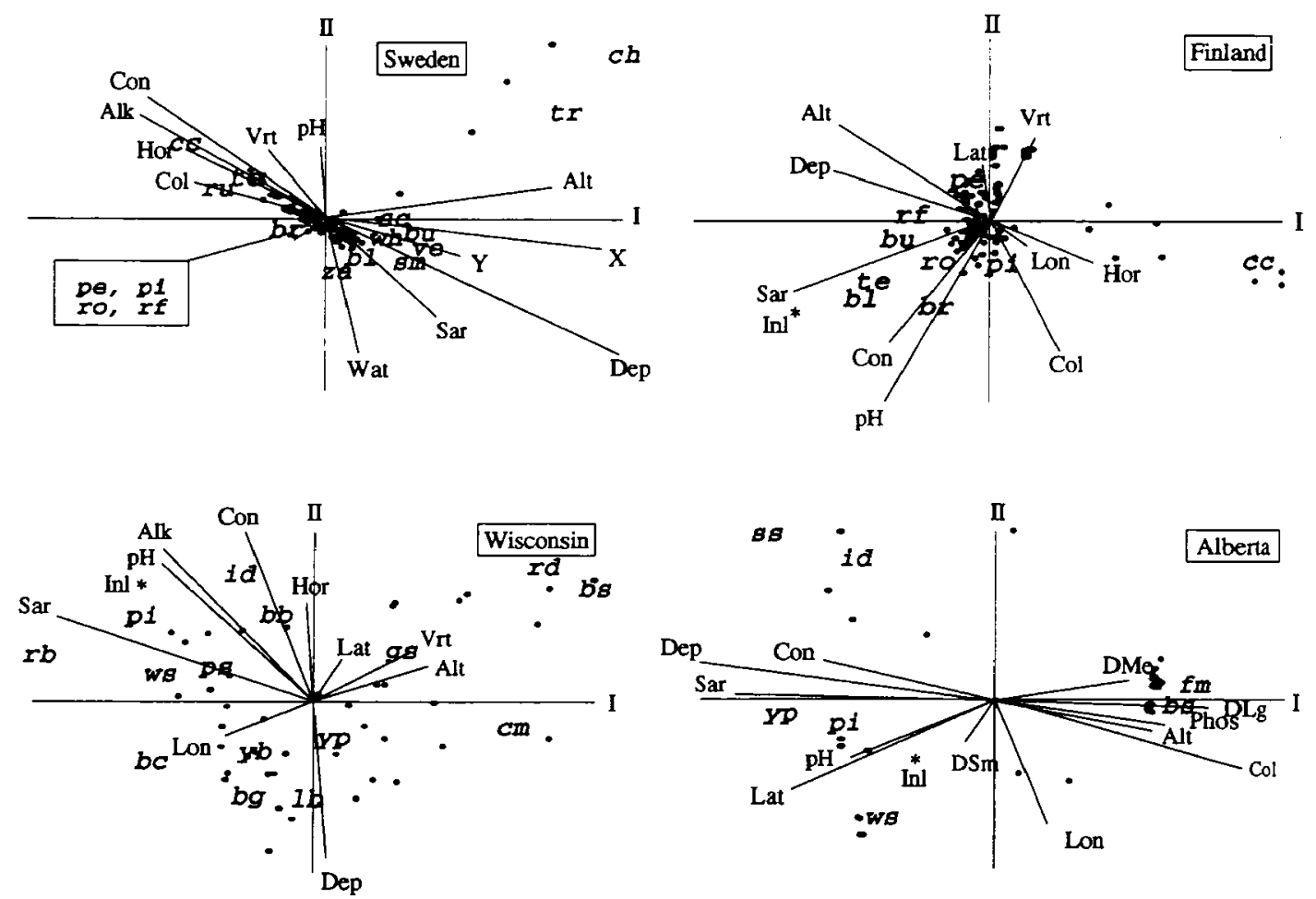

Figure 1 : Analyse canonique des correspondances triplot (CCA) des variables environnementales et des espèces de poissons en relation avec les peuplements de poissons de six régions. Les variables environnementales sont représentées par des flèches ou des astérisques (présencelabsence d'affluents) ; les positions des peuplements de poissons sont figurées par les points noirs ; les positions des espèces sont figurées par deux lettres italiques en caractères gras. Les codes des abréviations sont donnés en appendice.

Figure 1 : Canonical correspondence analysis (CCA) triplots of environmental variables and fish species in relation to small lake fish assemblages in six regions. Environmental variables are represented by arrows (quantitative variables) or centroids (presence/absence of inlets) ; filled circles give positions of the fish assemblages ; species points are represented by pairs of bold-faced, italicized letters. See Appendix for a key to abbreviations.

Finland. - Patterns of fish assemblage composition and assemblage-environment relations were described previously using principal components analysis (TONN et al., 1990). Consistent with that analysis and somewhat similar to the patterns observed in Sweden, the CCA aligned most Finnish fish assemblages along a tight, centrally-located continuum (Fig. 1) ; assemblages dominated by perch were located at the top of the continuum, with lakes dominated by roach, pike, bream and other species located below axis I (Fig. 1). Perch-dominated assemblages occurred in lakes that were more acidic, had lower conductivities, but were more isolated (indicated by greater vertical distances to the adjacent downstream lake and the general lack of inlets) than lakes dominated by roach (Fig. 1). Also similar to the Swedish assemblages was a group of small, shallow seepage lakes dominated by crucian carp. Overall, the CCA explained $26 \%$ of the variation in the species distribution patterns. 
Wisconsin.- TONN et al. (1990) had identified three broad types of fish assemblages, which could also be distinguished in the present analysis (Fig. 1) ; beginning in the upper right-hand corner and extending down toward the origin were lakes dominated by several small-bodied species : northern redbelly dace, brook stickleback, central mudminnow and golden shiner. Similar to the crucian carp lakes of Sweden and Finland, this group of lakes tended to be small, shallow and isolated. In the lower-central region of the ordination plot were lakes centered on largemouth bass, bluegill and yellow bullhead. These were deeper lakes with low conductivity. Finally, a group of assemblages characterized by northern pike, pumpkinseed and white sucker were located in the upper left quadrant. In contrast with the small-bodied assemblages, these were located in larger, more alkaline, drainage lakes. Overall, the CCA explained $38 \%$ of the variation in the data set.

Alberta.- Fish assemblages in Alberta can be divided into two or three major groups (Fig. 1). A tight cluster of lakes are characterized by the presence of fathead minnow and/or brook stickleback. Similar to the lakes containing the small-bodied species in Wisconsin (and crucian carp in northern Europe), these lakes are small, shallow and isolated (no inlets, long distances to nearby medium and large lakes ; see Table 1). A second, more diffuse group of lakes, which can be subdivided in two, is associated with the presence of northern pike and yellow perch. One subdivision of pike/perch assemblages is characterized by the presence of white sucker. Despite coming from a geographically limited study area, assemblage composition within this cluster of lakes was strongly correlated with latitude, as well as with $\mathrm{pH}$, maximum depth and surface area. Large, deep, but relatively clear-water lakes supported a second subdivision of pike/perch assemblages distinguished by the presence of spottail shiner and lowa darter. Overall, the CCA accounted for $59 \%$ of the variation in the fish assemblage patterns.

\section{habitat}

Partialling out the variation : relative importance of immigration, extinction and

The total amount of explained variation (as a percentage of the total variation of the species matrices) ranged from $25.9 \%$ (Finland) to $59.3 \%$ (Alberta ; Fig. 2). This is within the range of many community-level data sets (e.g., BORCARD et al., 1992). The higher amount of explained variation in Alberta is likely a consequence of it being a simpler data set (fewer species, presence-absence data) than the others, and the clear separation of fish assemblages into groups that were strongly associated with the measured environmental factors. Although the amount of explained variation was lower in the other data sets, clear, interpretable species-environment relations were apparent.

For all four data sets, extinction-related factors accounted for a majority of the explained variation. Indeed, there was a remarkable uniformity (84-88 \%) in the proportion of explained variation attributable to extinction factors, either independent of or overlapping with immigration factors. Differences did exist amongst the data sets in the relative proportion of explained variation that was attributable to immigration-related variables, especially in the proportion that overlapped with extinction (Fig. 2). Here, the data sets formed three groups: Wisconsin and Alberta both had relatively large amounts of explained variation associated with the immigration component (38-39\%), Finland had an intermediate proportion (30\%), whereas Sweden had a smaller amount (22\%). The latter data set was the most geographically diverse set of lakes and extinction variables associated with geography, especially the latitudinal X-coordinate, were strongly associated with the first canonical axis (Fig. 1) ; this likely minimized the relative importance of immigration-related factors. In Wisconsin, Alberta and Finland, morphometry and water chemistry were important as extinction factors (see below). However, small, shallow lakes are also often more isolated than larger lakes, and lakes with high values of alkalinity or conductivity are often large drainage lakes. Thus, there are closer limnological linkages of extinction- and immigrationrelated factors that can contribute to greater proportions of explained variation being associated with both kinds of factors in these three data sets (Fig. 2).

To gain further insights into the potential importance of extinction-related processes to the structure of fish assemblages, we decomposed the heterogenous set of extinction-related variables into more discrete subsets, associated with geography and the habitat-related factors of lake morphometry and water chemistry. To qualitatively 


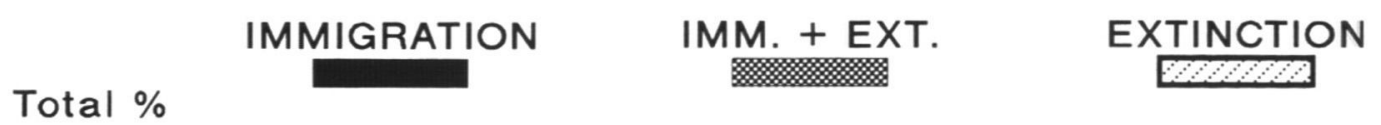

$\begin{array}{llll}\text { Explained: } & 34.0 & 25.9 & 37.8\end{array}$

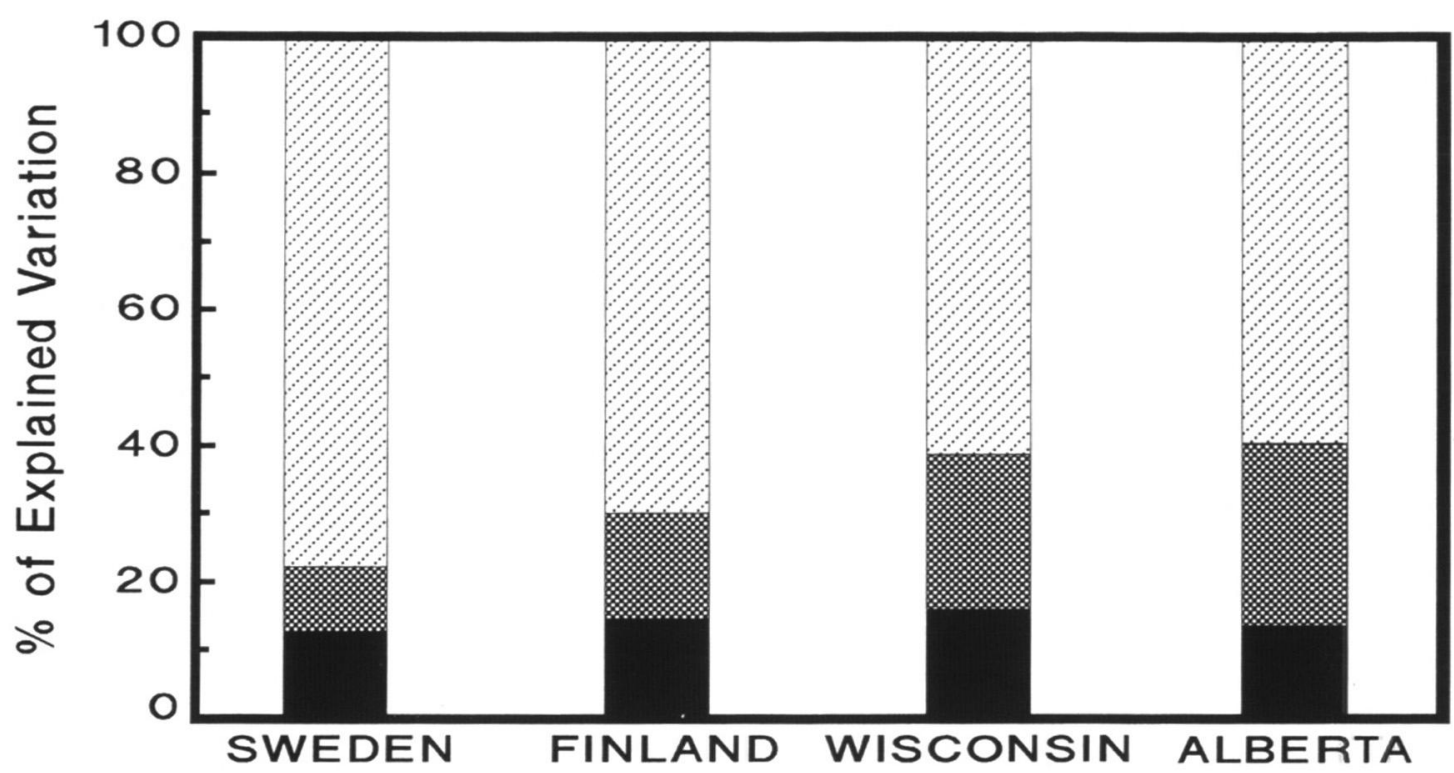

Figure 2 : Pourcentage de variation expliquée de la composition des peuplements de poissons de petits lacs forestiers de quatre régions, dérivé d'une série de CCA partielles (analyse canonique des correspondances), qui peut être attribuée aux variables environnementales principalement liées à l'extinction, à l'immigration et à la fois aux deux variables. Pour la nature de ces variables, voir le Tableau 1.

Figure 2 : The percentage of the explained variation in the composition of fish assemblages in small forest lakes of four regions, derived from series of partial CCAs (canonical correspondence analyses), that could be attributed to environmental variables linked principally to extinction, linked principally to immigration, and variation linked to both immigration and extinction variables. For the identity of these variables, see Table $\mathrm{I}$.

assess the relative importance of these subsets, along with immigration variables, to the community patterns, we applied CCA using the forward-selection procedure of CANOCO (ter BRAAK, 1991), from which we established a ranking of individual variables. Mean ranks of the top two variables within each of the three extinction subsets, plus immigration, were subsequently computed.

Consistent with the previous analyses, immigration factors were not highly ranked in any of the data sets (Fig. 3). In contrast, each of the three extinction-related subsets was ranked highly in two data sets, with the particular pattern of ranking varying between North America and northern Europe and between Finland and Sweden. Morphometry (area and depth) was highly ranked in both Wisconsin and Alberta ; a major pattern in these two North American regions was the presence of assemblages characterized by the presence of small-bodied fishes and the absence of piscivores. In both regions, the persistence of these small-bodied assemblages depends on the development of hypoxic winter conditions in these small shallow lakes, because hyoxia acts as a habitat filter that eliminates largebodied piscivores (TONN and MAGNUSON, 1982 ; ROBINSON and TONN, 1989). Chemistry was also important in Wisconsin, primarily separating two assemblage types 


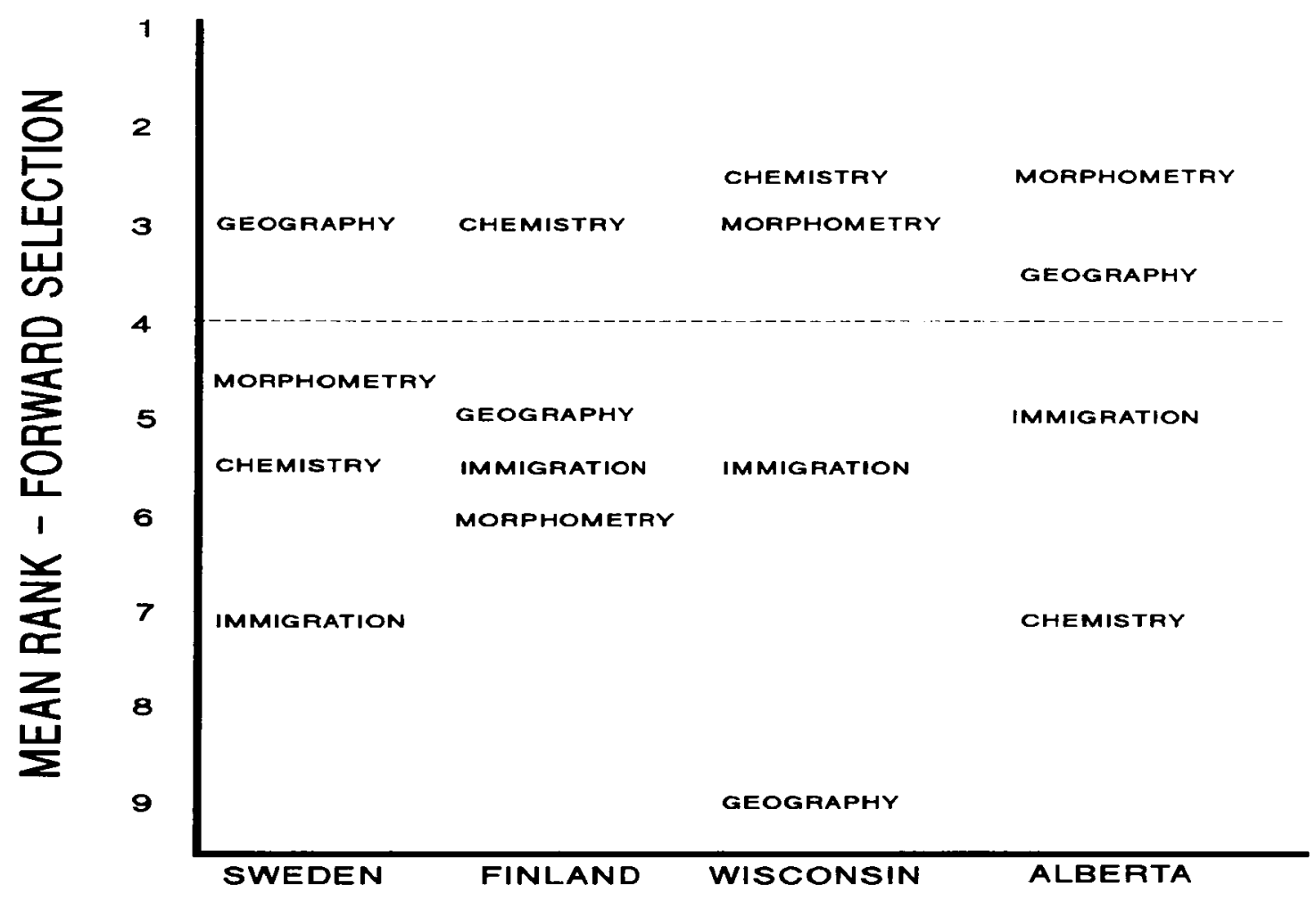

Figure 3 : Rang moyen de trois groupes de variables dépendant de l'extinction (géographie, morphométrie et physico-chimie) et d'un groupe de variables dépendant de l'immigration (voir Tableau I), selon l'ordre dans lequel ils rentrent dans une sélection ascendante des CCA réalisées sur les peuplements de poissons des petits lacs forestiers de quatre régions.

Figure 3 : Mean ranks of three sets of extinction-related variables (geography, morphometry, and chemistry) and one set of immigration-related variables (see Table I), in terms of the order in which they entered forward selection CCAs of fish assemblages in small forest lakes of four regions.

characterized by different piscivorous species. Assemblages with northern pike were found in larger drainage lakes having high values of $\mathrm{pH}$, alkalinity and conductivity, whereas assemblages with largemouth bass tended to occur in small (but deep) dystrophic bog lakes (Fig. 2 ; TONN and MAGNUSON, 1982). The importance of geography in Alberta was surprising, as the geographic range covered by the study lakes was not large. Across the geographic areas covered by the data sets from Finland and Sweden, geography reflects climate. However, in Athabasca County, Alberta, geography represents glacially-derived differences in soil types and lakes, with sandy areas concentrated in the north and small "prairie pothole" ponds located mostly in the south (C. PASZKOWSKI, W. TONN and R. VANDENBOS, personal observations).

Like Wisconsin, water chemistry (specifically, $\mathrm{pH}$ and color) was the highest ranking subset of habitat factors in Finland (Fig. 3). These variables were related to the perch/roach continuum and represent, in part, a severe-environment filter, because low $\mathrm{pH}$ restricts the presence and abundance of roach (JOHANSSON and MILBRINK, 1976). Although morphometry as a subset ranked low in Finland, surface area was highly significant, as shown by the Monte Carlo permutation test in CANOCO. The similarity in fish assemblage-lake environment relations between Wisconsin and Finland is further discussed by TONN et al. (1990). 
As expected, geographic factors, especially the climatically related $X$-coordinate and altitude, were ranked highly in the Swedish data set that extended across most of the country, from the temperate-zone of southernmost Sweden to the northern boreal forest. Both morphometric factors (area, depth) were also significant.

\section{DISCUSSION}

In all four sets of lakes, extinction-related factors dominated our analyses, suggesting that the results have some generality for fish assemblages in small forest lakes. Evidence from other systems is also consistent with our results (J. MAGNUSON, unpublished data ; CROWELL, 1986 ; WILCOX et al., 1986 ; DAVIS et al., 1988). In contrast, the structure of warm-water riverine fish communities was better correlated with connectivity to a tributary with high species richness than with local habitat diversity or area (OSBORNE and WILEY, 1992). As well, the distribution of fish species ranges among African rivers was closely associated with the species' dispersal abilities, rather than with extinction-related factors, suggesting the greater importance of immigration over extinction in fluvial systems (HUGUENY, 1990). Immigration has also proven important in determining species richness in immature systems relative to mature systems (MCCORMICK and CAIRNS, 1992).

LOMOLINO (1984) has argued that the relative importance of immigration is dependent not only on the rates of immigration (consistent with MACARTHUR and WILSON, 1967), but also on the range of rates available within an archipelago. Because small forest lakes are isolated systems, they are expected to have low rates of immigration and, perhaps, a limited range of immigration rates, both of which would minimize the influence of immigration. In terms of their maturity (sensu MCCORMICK and CAIRNS, 1992), the limited range of ages among small forest lakes should also be considered. When these lakes were formed, 10-12,000 years ago, immigration was likely a dominant mechanism, and we still see the effects of differential colonization at larger, regional scales (e.g., fish faunas of North America versus northern Europe, Wisconsin versus Alberta). However, regional immigration rates are currently low (but might increase with a changing climate). Extinction is likely a more continuous and frequent process in small lakes than is immigration, related to factors such as winterkill and $\mathrm{pH}$; immigration is likely more episodic and rare.

Finally, to what extent have anthropogenic effects altered immigration and extinction rates in these systems? Data are scanty, but examples can be found for which anthropogenic effects have increased both immigration and extinction rates (MAGNUSON and LATHROP, 1992). For smaller lakes, rates of fish introductions may depend on the isolation of lakes from human activities; the distance of a lake to the nearest road has been shown (J. MAGNUSON et al., unpublished data) or suggested (MAGNAN et al., 1995) to be an important immigration factor that contributes to patterns of fish assemblages. Paradoxically, however, fish introductions by humans could also magnify the measured effects of extinction-related factors, because the success or failure of introductions will depend on the environmental conditions of the receiving waters. THOMAS (1994) argues that extinction in human-influenced habitats is largely deterministic and results from habitats becoming unsuitable ; because emptied patches remain inappropriate for recolonization, extinction processes dominate. In fish assemblages of acidified Swedish lakes, extinction is seen as the dominant process even after lakes were reclaimed via liming because recolonization rates remain much lower than extinction rates (BERGQUIST, 1991). Thus, when analyzing data from surveys of fish assemblages in small forest lakes, whether in natural or human-influenced systems, it is more likely that the results of extinction processes will be observed.

\section{ACKNOWLEDGEMENTS}

We are very grateful to $P$. Gaudin and his organizing committee for the invitation to participate in the International Symposium on Fish and Their Habitat. This research was supported by the Natural Science and Engineering Research Council of Canada through research grants to WMT and CAP. Development of the Swedish data set was facilitated by a grant from the Swedish Council for Forestry and Agricultural Research to L. Greenberg and WMT. Finally, thanks are due to J. Magnuson for nearly $20 \mathrm{y}$ of discussions on this topic. 


\section{REFERENCES}

BENSON B.J., MAGNUSON J.J., 1992. Spatial heterogenity of littoral fish assemblages in lakes: relation to species diversity and habitat structure. Can. J. Fish. Aquat. Sci., 49, 1493-1500.

BERGQUIST B.C., 1991. Extinction and natural recolonization of fish in acidified and limed lakes. Nordic J. Freshw. Res., 66, 50-62.

BORCARD D., LEGENDRE P., DRAPEAU P., 1992. Partialling out the spatial component of ecological variation. Ecology, 73, 1045-1055.

BRORING U., 1991. Insular biogeography of Heteroptera on the East Frisian islands. Drosera, 0 (Suppl. 1), 1-96.

BROWNE R.A., 1981. Lakes as islands: biogeographic distribution, turnover rates, and species compostion in the lakes of central New York. J. Biogeogr., 8, 75-83.

BUHL-MORTENSEN L., HØISAETER T., 1993. Mollusc fauna along an offshore-fjord gradient. Mar. Ecol. Prog. Ser., 97, 209-224.

CONNOR E.F., MCCOY E.D., 1979. The statistics and biology of the species-area relationship. Am. Nat., 113, 791-833.

CORNELL H.V., 1986. Oak species attributes and host size influence cynipine wasp species richness. Ecology, 67, 1582-1592.

CROWELL K.L., 1986. A comparison of relict versus equilibrium models for insular mammals of the Gulf of Maine. Biol. J. Linn. Soc., 28, 37-64.

DAVIS R., DUNFORD C., LOMOLINO M.V., 1988. Montane mammals of the American Southwest : the possible influence of post-Pleistocene colonization. J. Biogeogr., 15, 841-848.

DIAMOND J., 1972. Biogeographic kinetics: estimation of relaxation times for avifaunas of southwest Pacific islands. Proc. Natl. Acad. Sci., 69, 3199-3203.

DIAMOND J., 1986. Overview: laboratory experiments, field experiments, and natural experiments. In DIAMOND J., CASE T.J., Community ecology, 65-79, Harper and Row, New York.

DIAMOND J., CASE T.J., 1986. Overview: introductions, extinctions, exterminations, and invasions. In DIAMOND J., CASE T.J., Community ecology, 65-79, Harper and Row, New York.

EADIE J.M., KEAST A., 1984. Resource heterogeneity and fish species diversity in lakes. Can. J. Zool., 62, 1689-1695.

EADIE J.M., HURLY T.A., MONTGOMERIE R.D., TEATHER K.L., 1986. Lakes and rivers as islands: species-area relationsips in the fish faunas of Ontario. Environ. Biol. Fish., 15, 81-89.

GAUCH H.G.JR., 1982. Multivariate analysis in community ecology. Cambridge University Press, Cambridge, $298 \mathrm{p}$.

GLEASON H.A., 1926. The individualistic concept of the plant association. Bull. Torrey Bot. Club, 53, 1-20.

HINCH S.C., COLLINS N.C., HARVEY H.H., 1991. Relative abundance of littoral zone fishes: biotic interactions, abiotic factors, and postglacial colonization. Ecology, 72, 1314-1324.

HOLMES J.C., 1986. The structure of helminth communities. In Howell M.J., Parasitology Quo Vadis? Proc. Six. Int. Cong. Parasitology, 203-208.

HOLT, R.D., 1992. A neglected facet of island biogeography: the role of internal spatial dynamics in area effects. Theor. Pop. Biol., 41, 354-371.

HUGUENY B., 1990. Geographic range of west African freshwater fishes: role of biological characteristics and stochastic processes. Acta CEcologica, 11, 351-375. 
JOHANSSON N., MILBRINK G., 1976. Some effects of acidified water on the early development of roach (Rutilus rutilus L.) and perch (Perca fluviatilis). Wat. Res. Bull., $12,39-48$.

LEVINS R., HEATWOLE H., 1973. Biogeography of the Puerto Rico bank: introduction of species onto Palmintos Island. Ecology, 54, 1056-1064.

LOMOLINO M. V., 1984. Mammalian island biogeography: effects of area, isolation and vagility. Oecologia, 61, 376-382.

LOMOLINO M. V., 1986. Mammalian community structure on islands: the importance of immigration, extinction and interactive effects. Biol. J. Linn. Soc., 28, 1-21.

MACARTHUR R.H., WILSON, E.O., 1967. The theory of island biogeography. Monogr. Pop. Biol., 1, Princeton Press, Princeton, NJ, USA, 203 p.

MAGNAN P., RODRÍGUEZ M.A., LEGENDRE P., LACASSE S., 1995. Dietary variation in a freshwater fish species: relative contributions of biotic interactions, abiotic factors, and spatial structure. Can. J. Fish. Aquat. Sci, in press.

MAGNUSON J.J., 1976. Managing with exotics - a game of chance. Trans. Am. Fish. Soc., $105,1-9$.

MAGNUSON J.J., LATHROP R.C., 1992. Historical changes in the fish community. In KITCHELL J.F., Food web management: a case study of Lake Mendota, 193-231, Springer-Verlag, New York.

MCCORMICK P.V., CAIRNS J JR, 1992. Limitations to long-term species accrual and development of microbial community structure in aquatic "islands". J. Freshwater Ecol., 7, 381-397.

MCGUINESS K.A., 1984. Equations and explanations in the study of species-area curves. Biol. Rev., 59, 423-440.

MOONEY H.A., DRAKE J.A., 1986. Ecology of biological invasions of North America and Hawaii. Springer-Verlag, New York.

MOULTON M.P., PIMM S.L., 1983. The introduced Hawaiian avifauna: biogeographic evidence for competition. Am. Nat.. 121, 669-690.

MOULTON M.P., PIMM S.L., 1986. Species introduction to Hawaii. In MOONEY H.A., DRAKE J.A., Ecology of biological invasions of North America and Hawaii, 231-249, Springer-Verlag, New York.

NELSON J.S., PAETZ M.J., 1992. The fishes of Alberta. University of Alberta Press, Edmonton.

NORDQUIST O., 1903. Some biological reasons for the present distribution of freshwater fish in Finland. Fennia, 20, 1-29.

NYBERG P., DEGERMAN E., 1988. Standardized test fishing with survey nets. Info. Inst. Freshw. Res., Drottningholm., 7, 1-18.

OSBORNE, L.L., WILEY M.I. 1992. Influence of tributary spatial position on the structure of warmwater fish communities. Can. J. Fish. Aquat. Sci. 49, 671-681.

RAHEL, F.J., 1986. Biogeographic influences on fish species composition of northern Wisconsin lakes with applications for lake acidification studies. Can. J. Fish. Aquat. Sci., 43, 124-134.

RAHEL F.J., MAGNUSON J.J., 1983. Low pH and the absence of fish species in naturally acidic Wisconsin lakes: inferences for cultural acidification. Can. J. Fish. Aquat. Sci., 40, 3-9.

RASK M., 1987. Effects of acid deposition on fish populations in small lakes of southern Finland. In PERRY R., HARRISON R.M., BELL J.N.B., LESTER J.N., Acid rain : scientific and technical advances, 528-532, Selper Ltd., London.

ROBINSON J.V., DICKERSON. 1984. Testing the invulnerability of laboratory island communities to invasion. Oecologia, 61, 169-174. 
ROBINSON J.V., DICKERSON. 1987. Does invasion sequence affect community structure? Ecology, 68, 587-595.

ROBINSON C.L.K., TONN W.M., 1989. Influence of environmental factors and piscivory in structuring fish assemblages of small Alberta lakes. Can. J. Fish. Aquat. Sci., 46, 81-89.

ROUGHGARDEN J., 1986. A comparison of food-limited and space-limited animal competition communities. In DIAMOND J., CASE T.J., Community ecology, 492-516, Harper and Rowe, New York.

SALE P.F., GUY J.A., STEEL W.J., 1994. Ecological structure of assemblages of coral reef fishes on isolated patch reefs. Oecologia, 98, 3-99.

SILVERTOWN J., WILSON J. B., 1994. Community structure in a desert perennial community. Ecology, 75, 409-417.

SIMPSON G.G., 1953. Evolution and geography. Condon Lectures, Oregon State System of Higher Education, Eugene OR, USA.

SMHI (SWEDISH METEROLOGICAL AND HYDORLOGICAL INSTITUTE), 1983. Svenskt sjöregister. Norrköping, Sweden, $313 p$.

SVÄRDSON G., 1976. Interspecific population dominance in fish communities of Scandinavian lakes. Rep. Inst. Freshw. Res., Drottningholm., 55, 144-171.

TER BRAAK C.J.F., 1991. CANOCO Version 3.12. Agricultural Mathematics Group, Wageningen, Netherlands.

THOMAS C.D., 1994. Extinction, colonization, and metapopulations: environmental tracking by rare species. Conserv. Biol., 8, 373-378.

TONN W.M., 1990. Climate change and fish communities: a conceptual approach. Trans. Am. Fish. Soc., 119, 337-352.

TONN W.M., MAGNUSON J.J., 1982. Patterns in the species compostion and richness of fish assemblages in northern Wisconsin lakes. Ecology, 63, 1149-1166.

TONN W.M., MAGNUSON J.J., RASK M., TOIVONEN J., 1990. Incontinental comparison of small-lake fish assemblages: the balance between local and regional processes. Am. Nat., 136, 345-375.

WIENS J.A., STENSETH N.C., VAN HORNE B., IMS R.A., 1993. Ecological mechanisms and landscape ecology. Oikos, 66, 369-380.

WILCOX B.A., MURPHY D.D., EHRLICH P.R., AUSTIN G.T., 1986. Insular biogeography of the montane butterfly faunas in the Great Basin: comparison with birds and mammals. Oecologia, 69, 188-194.

WILLIAMS E.E., 1983. Ecomorphs, faunas, island size, and diverse endpoints in island radiations of Anolis. In HUEY R.B., PIANKA E.R., SCHOENER T.W., Lizard ecology: studies of a model organism, Harvard University Press, Cambridge, MA, USA. 


\title{
APPENDIX
}

\author{
Environmental Variables and Fish Species \\ Used in Canonical Correspondence Analysis Triplots (Fig. 1).
}

\section{Environmental Variables}

Inl = Inlet, Vrt = Vertical distance to next lake downstream, Hor $=$ Horizontal distance to nearest lake, Wat $=$ Watershed area, $\mathrm{DLg}$ - Horizontal distance to nearest large lake, DMe - Horizontal distance to nearest medium-sized lake, DSm $=$ Horizontal distance to nearest small lake, Lat $=$ Latitude, Long $=$ Longitude, $X=X$ co-ordinate in the grid of Sweden, $Y=Y$ co-ordinate in the grid of Sweden, Sar = Surface area, Dep = Maximum depth, Con = Conductivity, $\mathrm{pH}=\mathrm{pH}$, Alk = Alkalinity, Phos = Phosphorus.

\section{Fish Species - Wisconsin and Alberta}

$\mathrm{bb}=$ black bullhead (Ameiurus melas), bc = black crappie (Poxomis nigromaculatus) $\mathrm{bg}=$ bluegill (Lepomis macrochirus), bs = brook stickleback (Culaea inconstans), $\mathrm{cm}=$ central mudminnow (Umbra limi), $\mathrm{fm}=$ fathead minnow (Pimephales promelas), gs = golden shiner (Notemigonus chrysoleucas), id = lowa darter (Etheostoma exile), $\mathrm{lb}=$ largemouth bass (Micropterus salmoides), $\mathrm{pi}=$ northern pike (Esox lucius), ps = pumpkinseed (Lepomis gibbosus), rb = rock bass (Ambloplites rupestris), $\mathrm{rd}=$ northern redbelly dace (Phoxinus eos), $s s=$ spottail shiner (Notropis hudsonius), ws = white sucker (Catostomus commersoni), yb = yellow bullhead (Ameiurus natalis), yp = yellow perch (Perca flavescens).

\section{Fish Species - Finland and Sweden}

$\mathrm{bl}=$ bleak (Alburnus alburnus), br = bream (Abramis brama), bu = burbot (Lota lota), $\mathrm{cc}=$ crucian carp (Carassius carassius), $\mathrm{ch}=\operatorname{arctic}$ char (Salvelinus alpinus), pe $=$ perch (Perca fluviatilis), $\mathrm{pi}=$ pike (Esox lucius), $\mathrm{rf}=$ ruffe (Gymnocephalus cernua), $\mathrm{ru}=$ rudd (Scardinius erythrophthalmus), ro = roach (Rutilus rutilus), sc = sculpin (Cottus gobio), $\mathrm{sm}=$ smelt (Osmerus eperlanus), te $=$ tench (Tinca tinca), $\mathrm{tr}=$ brown trout (Salmo trutta), $\mathrm{ve}=$ vendace (Coregonus albula), $\mathrm{wh}=$ whitefish (Coregonus spp.), za = zander (Stizostedion lucioperca). 